\title{
Covenant action to facilitate integrated river basin management ${ }^{\#}$
}

\author{
Bruce P Hooper* \\ PO Box 6119, St Lucia Sth. QLD 4067. AUSTRALIA
}

\begin{abstract}
This paper outlines elements of best practice integrated river basin management and explores a procedure to implement IRBM. The procedure identifies a 'road map' for improved governance based on a best practice approach, with initial trialling in a UNESCO HELP basin in North America showing some application. But even with best practices understood, action is often only minimal and flexible, adaptable institutions are needed to underpin basin management. The covenant concept is one such institution, based on the idea of harnessing mutual trust and obligation between stakeholders. A covenant is 'signed' as a social contract and the idea of covenant described in this paper results from observations of intractable water sharing problems. This paper also outlines the components of a covenant, the factors which require consideration for implementation and ways forward.
\end{abstract}

Keywords: covenants, mutual responsibility, integrated water resources management, basin governance

\section{Introduction}

Integrated river basin management involves the coordinated management of land and water resources for multiple purposes and across different sectors. It is a subset of integrated water resource management (IWRM) operating at the basin scale. This paper draws on previous work in the development of basin organisation performance indicators for IWRM (Hooper, 2006) and extends that work, focusing on the role of covenants as an enacting mechanism.

The paper is dividend into two parts: firstly, a discussion on IWRM which reports the development of functional measures of relevance and effectiveness, and secondly, an exploratory discussion about a covenant of mutual obligation, a suggested institution to implement IWRM in river basins. The first section provides insight into the array of functional elements of IWRM. This checklist is valuable as it demonstrates the complex and related tasks required to establish and maintain land and water resources management. Accepting this array of tasks, the second section outlines a mechanism to implement actions using a covenant of mutual obligation. This will not be a first task for a basin organisation but one which evolves through time after trust and respect have been established between stakeholders and agreement reached regarding required natural resources management actions and water shares in a river basin. This is more likely to occur when basin organisations have reached a mature level of functional development, which includes stakeholder participation, ongoing funding, basin advocacy and political support. The paper concludes with a discussion of ways forward.

\footnotetext{
Revised paper. Originally presented at the symposium 'HELP in Action: Local Solutions to Global Water Problems - Lessons from the South' which was held at the Emperor's Palace, Johannesburg, South Africa from 4 to 9 November 2007.

* To whom all correspondence should be addressed.

疋 +61 43102 1289; e-mail: bph@dhigroup.com
}

\section{Integrated water resource management effectiveness}

The management of water resources at basin scales continues to be a challenge. One of the critical issues is the coordination of management between different sectors and across different disciplines and groups. IWRM is one method which articulates this approach to coordinated management (Fig. 1).

The decisions made to manage land and water resources using this integrated approach involve many stakeholders operating at different scales. Stakeholders include individual water users, government agencies, private sector interests, non-

\section{Towards a new paradigm}

- from sub-sectoral to cross-sectoral water management

IWRM is the 'Integrating handle' leading us from sub-sectoral to cross-sectoral water management.

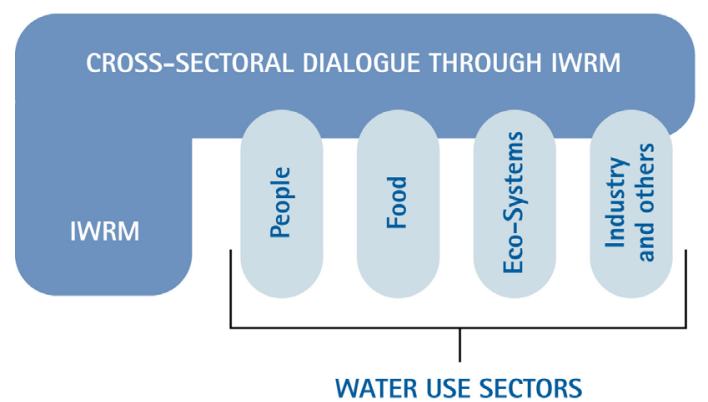

IWRM is a process which promotes the coordinated development and management of water, land and related resources in order to maximise the resultant economic and social welfare in an equitable manner without compromising the sustainability of vital ecosystems (GWP/TAC).

Figure 1

Integrated water resources management, conceptualised as a cross-sectoral dialogue (Global Water Partnership Technical Advisory Committee, 2000) 


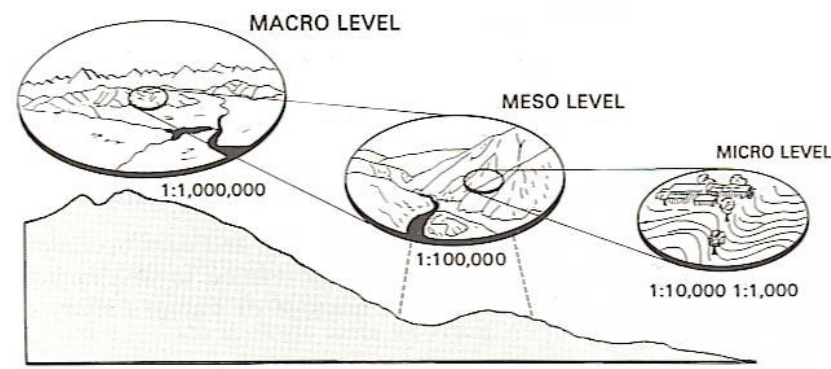

Figure 2

Scales, mapping, decision making, organisations and documents in integrated river basin management

\begin{tabular}{|l|l|l|l|}
\hline \multirow{2}{*}{$\begin{array}{l}\text { Natural System and } \\
\text { Resources }\end{array}$} & MACRO LEVEL & MESO LEVEL & MICRO LEVEL \\
\cline { 2 - 4 } & $\begin{array}{l}\text { Part of a geographical zone such as a river } \\
\text { basin or different ecological zones }\end{array}$ & Regional or local ecological resource system & $\begin{array}{l}\text { Areas with relatively uniform ecological } \\
\text { conditions }\end{array}$ \\
\hline Mapping scale & $>1: 1000000$ & $1: 100000-1: 500000$ & $1: 100001: 1000$ \\
\hline Mapping unit & Provinces & Land systems & Land units, land facets \\
\hline $\begin{array}{l}\text { Level of decision- } \\
\text { making }\end{array}$ & NATIONAL OR INTERNATIONAL LEVEL & REGIONAL LEVEL & LOCAL LEVEL \& INDIVIDUAL \\
\cline { 2 - 4 } & $\begin{array}{l}\text { Highest political decision-making, } \\
\text { international agreements }\end{array}$ & Province, State, District, Territory & $\begin{array}{l}\text { Village cooperative, farm, factory, forest, } \\
\text { individual }\end{array}$ \\
\hline $\begin{array}{l}\text { IRBM organisation } \\
\text { example }\end{array}$ & National or international commission & $\begin{array}{l}\text { Inter state basin commission/authority/ } \\
\text { association }\end{array}$ & Local land and water management group \\
\hline $\begin{array}{l}\text { IRBM document } \\
\text { examples }\end{array}$ & National or international agreement & River basin management plan & $\begin{array}{l}\text { Land and water management plan, storm } \\
\text { water management plan }\end{array}$ \\
\hline
\end{tabular}

Adapted from (Newson, 1992). Source (Hooper, 2005) p. 120.

government organisations and lobby groups, and those who do not have a distinct 'voice' because of poverty or accessibility: because they do not have access to powerful decision makers in the water sector. The scale at which IWRM takes place varies from local to international (Fig. 2), but at the basin scale decisions for river basin management occur at macro and meso scales.

Effective basin management in the water sector is not linear, prescriptive and logical; rather it tends to be adaptive and 'messy', responding to the dynamic nature of existing political and economic forces and in response to varying environmental conditions (floods, hurricanes, droughts). Adaptive management has been advocated as a desired approach to natural resources management in watersheds (National Science Council, 2002; Sabatier et al., 2005). Integrated-adaptive management of land and water resources offers promise in terms of delivering effective management of natural resources. However, the challenge is to identify what is good practice and build the capacity of basin organisations to deliver IWRM. The earlier work reported here suggests five broad groups of functions form good practice, summarised as twenty-one activities, all of which can be evaluated in a basin setting (Table 1). This approach draws on and extends the work of international studies of implementing river basin management (World Bank, 2006).

The prescriptive tasks listed in Table 1 suggest a procedure similar to a 'triage' in medicine, in that they allow the users to identify then ascertain the effectiveness of functions in river basin management and prescribe actions to implement IWRM (the activities would generate low scores in the evaluation table). The measurements provided in the relevance and effectiveness scores are provided either by individual managers or, to be more useful, scored in a workshop setting with basin managers and their stakeholders through dialogue. Both are self-assessment procedures. They can also be used to report progress to stakeholders in river basin management and account for investments made to funding bodies, at least in a qualitative way, but will require additional analysis using techniques such as cost-benefit or multi-criteria analysis to account for returns on investment in river basin management programs. When coupled with economic and social indicators of livelihoods of basin societies and biophysical indicators of the conditions of natural resources and ecosystems, these governance measures provide a useful picture of the effectiveness of river basin management using an IWRM approach. Trialling of performance indicators using this procedure in a UNESCO HELP basin (Willamette, Oregon, USA) showed initial promise, but more work was required to specify the relevance of individual indicators to that case (Hooper, 2006).

The implementation of functions listed in Table 1 may not occur sequentially although there is a general tendency in river basin management to progress from Group 1 to 5 . Nor is there agreement on whether these functions are those deemed most effective for implementing integrated approaches to land and water management (Sabatier et al., 2005). However, the list is more than suggestive and embraces the commonly accepted dimensions of IWRM (an enabling environment, institutional roles and management instruments) as promoted by capacity building organisations such as the Global Water Partnership (Global Water Partnership, 2002).

Table 2 illustrates a possible sequence in the development of functionality, and hence capacity, of river basin organisations. In this hypothetical sequence, river basin organisations evolve from focusing on data analysis, project development and implementation to organisations which have the ability to respond rapidly to new situations. These new situations arise from new knowledge (for example about climate change, drought and flood hazards, and new technologies for water efficiency), from new political circumstances (for example in democracies, being able to transit through elections when new political parties come to power while still maintaining basin management functions) and from new economies (for example, being able to manage the impacts of sustained land use change through increasing urbanisation). 


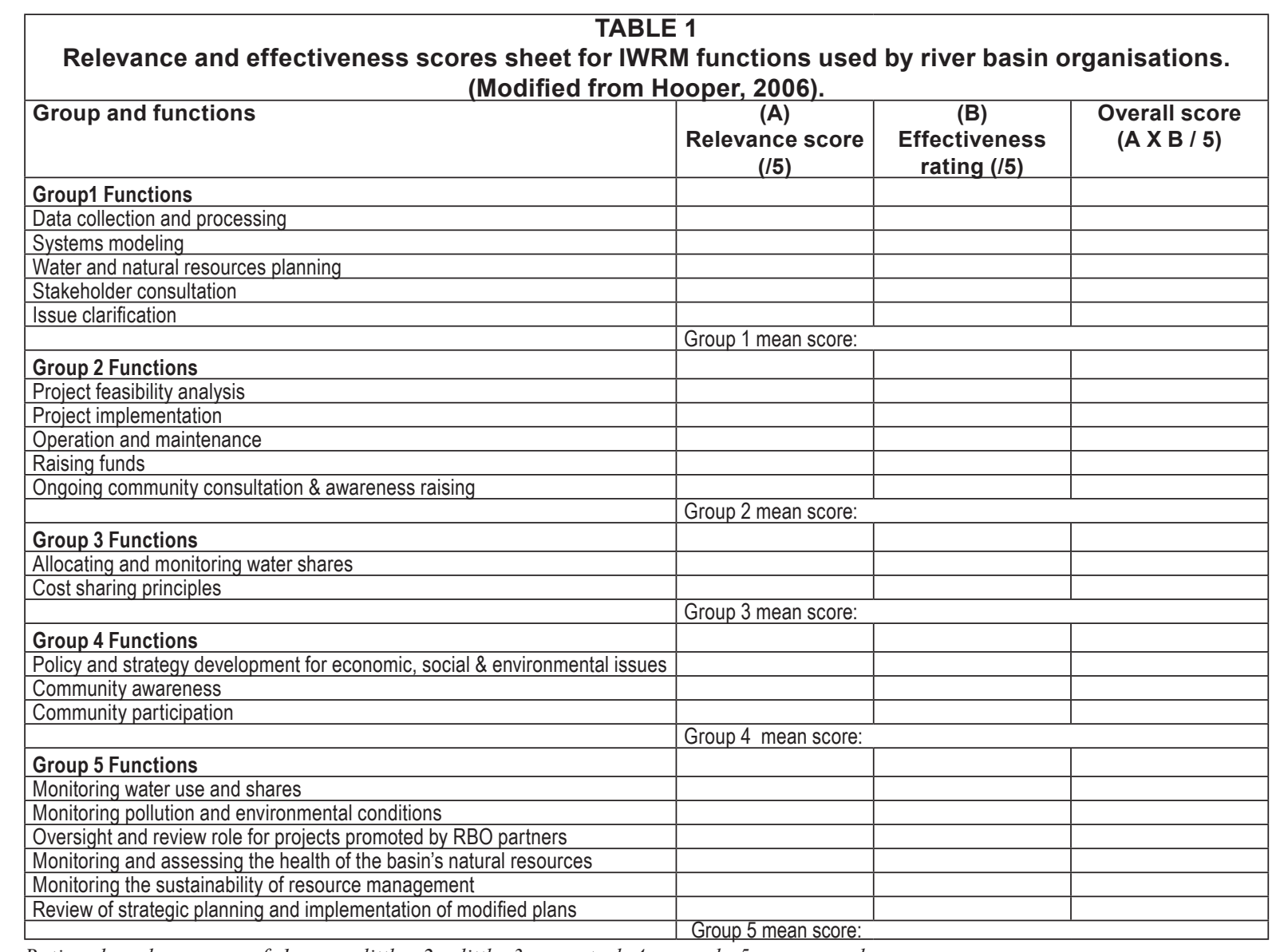

Ratings based on scores of: $1=$ very little; $2=$ little $3=$ neutral; $4=$ much; $5=$ very much

\begin{tabular}{|c|c|c|c|}
\hline \multicolumn{4}{|c|}{$\begin{array}{c}\text { TABLE 2 } \\
\text { Stages in the evolution of an adaptive river basin organisation. } \\
\text { Source: Hooper (2006), modified from Comfort (1999); World Bank (2006) }\end{array}$} \\
\hline Functions & $\begin{array}{c}\text { Initial/ } \\
\text { Functionary } \\
\text { RBO }\end{array}$ & $\begin{array}{l}\text { Emerging } \\
\text { Auto-adap- } \\
\text { tive RBO }\end{array}$ & $\begin{array}{l}\text { Mature Auto- } \\
\text { adaptive } \\
\text { RBO }\end{array}$ \\
\hline $\begin{array}{l}\text { Group 1: Water (and natural resource) data collection and processing, systems modeling, water and } \\
\text { natural resources planning, stakeholder consultation \& issue clarification }\end{array}$ & $x$ & $x$ & $x$ \\
\hline $\begin{array}{l}\text { Group 2: Project feasibility, design, implementation, operation and maintenance, raising funds, } \\
\text { ongoing community consultation and awareness raising }\end{array}$ & $x$ & $x$ & $x$ \\
\hline $\begin{array}{l}\text { Group 3: Allocating and monitoring water shares (quality and quantity and possible natural resources } \\
\text { sharing), cost sharing principles }\end{array}$ & & $x$ & $x$ \\
\hline $\begin{array}{l}\text { Group 4: Policy and strategy development for economic, social and environmental issues, commu- } \\
\text { nity awareness and participation }\end{array}$ & & & $x$ \\
\hline $\begin{array}{l}\text { Group 5: Monitoring water use and shares, monitoring pollution and environmental conditions, } \\
\text { oversight and review role for projects promoted by RBO partners, monitoring and assessing the } \\
\text { health of the basin's natural resources, monitoring the sustainability of resource management, review } \\
\text { of strategic planning and implementation of modified plans }\end{array}$ & & & $x$ \\
\hline
\end{tabular}

\section{Covenants of mutual obligation}

Coordination mechanisms and conflict resolution procedures are prerequisites for management as mistrust and disputes frequently arise in basin water sharing. For example, agencies, watershed councils and other stakeholders progressed an integrated approach in southwest Oregon by adopting collaboration, in which tensions between technical complexity and open participation were addressed, while also addressing difficulties with information exchange for joint management, the relationship between technical issues and policy issues, the role of regional policy in supporting collaborative efforts, and the importance of strengthening institutional arrangements (Margerum and Whitall, 2004). This study echoed the results of earlier analyses of large- and small-scale water resources and catchment (watershed) management planning in Australia (AACM International \& Centre for Water Policy Research, 1995), United States (Kenney, 1997) and South Africa (Van Zyl, 1995). Together, these studies suggest a need for flexible, adaptable organisations to facilitate basin management through coordination processes. These organisations also require clear specification of the roles and responsibilities separate from their respective water resources 
agencies with whom they work (Saleth and Dinar, 1999), while others have suggested that transforming existing water organisations (such as river commissions) into 'whole of river basin' organisations requires significant and incremental organisational change and capacity building (World Bank, 2006). This includes reforming existing organisations and institutions to become new basin organisations which focus on IWRM.

River basin management requires clear specification of roles and responsibilities of government agencies, the private sector, non-government organisations and other stakeholders. Once established, procedures to develop strategies for integrated river basin management are required. They usually take the form of river basin planning procedures, which involve the allocation of land and water resources to optimise national (or international) investments (often linked to water rights adjudications), and result in a basin management plan or strategy, supported by legalisation and water policy within the country or within countries which share basins. Modelling of resource use options and an up-to-date information system are needed to support this approach and to identify optimal solutions.

However, the pervading challenge remains: to implement strategies for integrated river basin management. What follows draws largely from initial work on a concept developed by the author and aims to extend that work (Hooper, 2005). The common meaning of 'covenant' is a technical one, referring to a constraint on a land title. But this is not the meaning here, rather it is an ethical one, referring to the biblical concepts of promise keeping, shared, reciprocal responsibility and mutual trust. The covenant concept is based on the idea that basin stakeholders harness mutual trust and obligation between and towards each other: it is about maintaining relationships. This takes years to achieve and is done by deliberate negotiation and reaching agreement on ways forward. The obligations towards each other (usually for water shares) are signed as a basin management agreement. The covenants which result from this process are agreements for action which require reciprocal action and 'contributions' in time, resources, and basin works (soil conservation plans, stream restoration, water sharing plans, plans for environmental flows). They form tangible products of the mutually shared values of trust.

The covenant of mutual obligation concept can be extended to include:

1. A common vision statement: A statement of the desired future for land and water resources management within, say, a 25 year period, and longer if possible.

2. A statement of the current state of the water resources and water shares (which requires rigorous ex-ante assessment) and assessment of benefit shares; the specification of benefit shares accorded to each stakeholder in water sharing arrangements will be explicit and transparent - able to be externally audited and reviewed.

3. Identification of stakeholders: their roles, responsibilities and values.

4. Cost-sharing plan: Identification of cost-sharing arrangements to share river basin management expenses: who pays, what are the benefits accrued and how they are distributed.

5. Responsibilities: Clear specification roles of river basin management organisations and their stakeholders to undertake works and targeted actions, and who is responsible for each.

6. Specifying rights: The covenant will clearly identify and specify water rights and mechanisms which facilitate water trading in economies where a trading environment is possible.
7. Contractual agreements: Contracts will be used to exercise the covenantal relationships between stakeholders to undertake actions, share and manage water resources. Contracts can be legally binding documents and in national river basins (within a country) an appropriate legal framework will exist for the creation of contracts. In international basins, appropriate legal instruments can be used such as the United Nations Convention on the 'Law of the Nonnavigational Uses of International Water Courses', adopted in 1997 (United Nations, 1997). This convention is based on the principles of 'equitable and reasonable utilisation' of water resources, in which basin states can attain optimal and sustainable utilisation of their watercourses while ensuring their adequate protection (Article 5) and 'mutual obligation' not to cause significant harm to shared water resources between countries in a river basin (Article 7).

There are several factors which require consideration when implementing covenants of mutual obligation:

- Leadership: building and maintaining strong leadership of the 'engaged' stakeholders

- Ensuring membership of river basin management organisations is on a skills basis, not a representative basis so as to enact technical components of the contractual arrangement

- Developing trust between all stakeholder groups to agree on each other's mutual obligations, using conflict resolution facilitators

- Ensuring a sustained funding base

- Designing a clear definition and adjudication of property rights, including those of disenfranchised groups (such as those in abject poverty), and facilitation mechanisms which allow better opportunities for water transfers to new uses as needs arise

- Knowledge of why water managers are unable and unwilling to adopt sustainable land and water management practices, and mechanisms to facilitate the uptake of best practices

- Use of decision support and information exchange tools such as interactive basin information systems

- Existence of a central government agency to establish mechanisms to create national or international river basin organisations and to create and manage covenants.

The creation of covenants of mutual obligation suggests the prerequisite of democratic governance, in which there are free elections, free speech and individual freedoms. Without these societal characteristics, there are limited opportunities to establish dialogue processes and hold elections for leaders to emerge from society to create basin organisations, provide basin advocacy and leadership within government and build trust.

\section{Conclusion and ways forward}

The approach outlined in this paper is one based on first-hand experience of water conflicts, basin management malaise and limited adoption of best practices by agriculturalists in catchment management, primarily in Australian, Indian and US experiences over the last twenty years (Hooper, 2005). The approach can add vale to UNESCO's Theme 4 for the 2007 HELP Symposium by identifying a mechanism which is rooted in an international convention (as documented above), and which offers some promise in addressing intractable water sharing problems.

The approach outlined here has not been tried and tested - it is very 'embryonic'. It was developed knowing what is commonly recognised as 'best practice' integrated river basin 
management. The procedures for developing best practice were briefly discussed in this paper and more information about best practice can be obtained in the references below. However, the second purpose of this paper is to progress the implementation of best practice using covenants.

There are several ways to progress a covenant-based approach:

- The initial task is to develop the concept further, as it applies to existing laws on water sharing, including American-style compacts which specify water shares through time and space

- Clarify further the seven components of covenants listed above and demonstrate their flexibility and adaptability to a range of contexts

- Identify the added value this approach brings to integrated river basin management, compared to existing arrangements or a 'do nothing' scenario. This includes quantifying the costs and benefits of covenants, using ex-ante and expost assessments.

- Identify procedures for the use of covenants in societies with very limited or non-existent democratic governance. Here there may not be well-developed water institutions, or a functioning procedure of decision-making about the sharing of waters between groups at national scales. However, in some traditional societies, there is an opportunity to examine existing water institutions and identify ways by which covenants can have a role. In these societies, there will be the need to recognise the multitude of small-scale water organisations or individual decision-making processes where water is shared and to develop appropriate ways to incorporate values of trust and mutual obligation. Mature, highly developed water economies may require different procedures.

- Specification of procedures to involve disenfranchised groups in covenant arrangements.

- Identification of leverage points for implementing covenants, relevant to specific societies.

\section{References}

AACM INTERNATIONAL AND CENTRE FOR WATER POLICY RESEARCH (1995) Enhancing the Effectiveness of Catchment
Management Planning. Final Report for the Department of Primary Industries and Energy. Adelaide, AACM International Pty. Ltd.

COMFORT L (1999) Shared Risk: Complex Systems in Seismic Response. Pergamon Press, New York.

GLOBAL WATER PARTNERSHIP TECHNICAL ADVISORY COMMITTEE (2000) Integrated Water Resources Management. TEC Paper \#4. Stockholm, Global Water Partnership.

GLOBAL WATER PARTNERSHIP (2002) Integrated Water Resources Management Toolbox. Stockholm, Global Water Partnership.

HOOPER BP (2005) Integrated River Basin Governance. Learning from International Experience. London, IWA Publishing.

HOOPER BP (2006) Key Performance Indicators of River Basin Organizations. [2006-VSP-01]. Alexandria, Virginia, US Army Corps of Engineers. Visiting Scholar Program.

KENNEY DS (1997) Resource Management at the Watershed level: An Assessment of the Changing Federal Role in the Emerging Era of Community-Based Watershed Management. Boulder, Colorado, Natural Resources Law Center, University of Colorado School of Law.

MARGERUM RD and WHITALL D (2004) The challenges and implications of collaborative management on a river basin scale. J. Environ. Plann. Manage. 47 (3) 407-427.

NATIONAL SCIENCE COUNCIL (2002) The Missouri River Ecosystem. Exploring Prospects for Recovery. National Academy Press, Washington, DC.

NEWSON M (1992) Land, Water and Development. River Basin Systems and Their Sustainable Management. Routledge, New York, USA.

SABATIER P, FOCHT W, LUBELLM, TRACHTENBERGZ, VEDLITZ A and MATLOCK M (2005) Swimming Upstream: Collaborative Approaches to Watershed Management. The MIT Press, Cambridge, Massachusetts.

SALETH,R.M and DINAR A (1999) Evaluating Institutions and Water Sector Performance. No. 447, 1-93. Washington, DC, The World Bank. World Bank Technical Paper.

UNITED NATIONS (1997) Convention on the Law of the Non-navigational Uses of International Watercourses. Adopted by the General Assembly of the United Nations on 21 May 1997. Not yet in force. See General Assembly resolution 51/229, annex, Official Records of the General Assembly, Fifty-first Session, Supplement No. 49. (A/51/49). http://untreaty.un.org/ilc/texts/instruments/english/conventions/8_3_1997.pdf.

VAN ZYL FC (1995) Integrated catchment management: is it wishful thinking or can it succeed? Water Sci. Technol. 32 27-35.

WORLD BANK (2006) Integrated River Basin Management - From Concepts to Good Practice. Briefing Notes. Washington, DC, World Bank/Bank-Netherlands Water Partnership Program/World Bank Institute. 